\title{
Phenotypic diversity and carcass quality of creole goats with genetic potential for resistance to infection caused by worm
}

\author{
Vanessa dos Santos Neri(1), José Lindenberg Rocha Sarmento(2), Laylson da Silva Borges ${ }^{(1)}$, \\ Tatiana Saraiva Torres ${ }^{(1)}$, Luciano Silva Sena ${ }^{(1)}$, Max Brandão de Oliveira( ${ }^{(3)}$ and Antônio de Sousa Júnior ${ }^{(4)}$

\begin{abstract}
(1)Universidade Federal do Piauí, Centro de Ciências Agrárias, Campus Universitário Ministro Petrônio Portella, Ininga, CEP 64049-550 Teresina, PI, Brazil. E-mail: vs.neri2@gmail.com, laylson_borges@hotmail.com, tatianaana@hotmail.com, lucianossbj@hotmail.com (2)Universidade Federal do Piauí, Centro de Ciências Agrárias, Departamento de Zootecnia, Campus Universitário Ministro Petrônio Portella, Ininga, CEP 64049-550 Teresina, PI, Brazil. E-mail: sarmento@ufpi.edu.br (3)Universidade Federal do Piauí, Departamento de Estatística, Campus Universitário Ministro Petrônio Portella, Ininga, CEP 64049-550 Teresina, PI, Brazil. E-mail: maxbrandao@gmail.com ${ }^{(4)}$ Colégio Técnico de Teresina, Campus Universitário Ministro Petrônio Portella, Ininga, CEP 64049-550 Teresina, PI, Brazil. E-mail: sousajunior@ufpi.edu.br
\end{abstract}

\begin{abstract}
The objective of this work was to phenotypically characterize creole goats of the Moxotó, Azul, Canindé, Repartida, Marota, and Graúna breeds, comparing them with the Boer, Anglo Nubian, and Alpine exotic breeds, to identify the genetic groups of greater potential for carcass quality and resistance to infection caused by worm. Data on morphometric measurements were obtained for the count of worm eggs in grams of feces (WEGF), Famacha score, carcass measurements, and body weight from 308 animals, in a farm in the state of Piauí, Brazil. Repartida goats showed the highest average for wither height $(61.55 \mathrm{~cm})$ and rump height $(62.16$ $\mathrm{cm})$, and Moxotó goats had the greatest ear length $(13.45 \mathrm{~cm})$. The Moxotó breed showed the highest means for carcass and body weight. The lowest average for body weight was observed in Azul goats (24.35 kg), and the lowest WEGF was detected in Repartida goats (200 eggs per gram of feces). The average Famacha score was 2.77. Average linkage was the method that best summarized the information on the morphometric and carcass data. The use of morphometric and carcass measurements provides satisfactory results in the phenotypic characterization of the animals. The Brazilian creole goats, which are considered resistant to worm infection and show high-quality carcass traits, may be indicated for conservation and genetic breeding programs.
\end{abstract}

Index terms: carcass traits, genetic resources, morphometry, resistance.

\section{Diversidade fenotípica e qualidade das carcaças de caprinos crioulos com potencial genético quanto à resistência à verminose}

Resumo - O objetivo deste trabalho foi caracterizar fenotipicamente caprinos crioulos das raças Moxotó, Azul, Canindé, Repartida, Marota e Graúna, em comparação às raças exóticas Boer, Anglo Nubiana e Alpina, para identificar grupos genéticos de maior potencial para qualidade de carcaça e resistência à verminose. Dados de medidas morfométricas foram obtidos quanto à contagem de ovos de vermes por grama de fezes (OVGF), ao escore Famacha, às medidas de carcaça e ao peso corporal de 308 animais de uma fazenda no Estado do Piauí. Os caprinos Repartida apresentaram a maior média de altura de cernelha $(61,55 \mathrm{~cm})$ e altura de garupa $(62,16$ $\mathrm{cm})$, e os caprinos Moxotó, o maior comprimento de orelha $(13,45 \mathrm{~cm})$. A raça Moxotó apresentou as maiores médias de carcaça e peso corporal. O menor peso corporal médio foi dos caprinos Azul (24,35 kg), e o menor valor de OVGF foi o dos caprinos Repartida (200 ovos por grama de fezes). Para o escore Famacha, a média foi 2,77. O método da ligação média foi o que melhor resumiu a informação dos dados morfométricos e de carcaça. $\mathrm{O}$ uso de medidas morfométricas e de carcaça apresentou resultados satisfatórios na caracterização fenotípica dos animais. Os caprinos crioulos, considerados resistentes à verminose e com características de carcaça de boa qualidade, poderão ser indicados para programas de conservação e melhoramento genético.

Termos para indexação: características de carcaça, recursos genéticos, morfometria, resistência.

Introduction

Goats were introduced in Brazil during the colonization period and formed the regional genetic groups of the Northeastern region, showing traits of rusticity and adaptation to this region climatic conditions. Therefore, they constitute the great differential of goat farming, in comparison with the other livestock activities (Pires et al., 2017). 
The caprine herd in Brazil is composed of over 9.6 million heads, and the Northeast region accounts for 92.7\% of this total (Produção..., 2015). The effective size, phenotypic pattern, and economic aptitude of most Brazilian indigenous goat populations in the country are not known, and some areas have no longer any population of these animals, which renders them a critical level of extinction (Costa et al., 2016).

Faveira farm, located in the municipality of Elesbão Veloso, in the state of Piauí, Brazil, is home to some genetic groups of Brazilian creole goats - the Moxotó, Graúna, Marota, Repartida, Azul, and Canindé breeds -, which are exploited for meat production, representing an important center for conservation and preservation of the animal genetic heritage in the state. According to Pires et al. (2017), these animals remain among those brought by the settlers and, under adverse environmental conditions, were subjected to natural selection, acquiring their small size, rusticity, and high-prolificacy traits. In addition to Brazilian indigenous goats, there are also the Alpine, Boer, and Anglo Nubian exotic breeds, which unfortunately put the genetic preservation of local goat breeds at risk due to disorderly crosses among them.

The degradation of the natural environment, notably the Caatinga biome, and the disorderly use of animals in crosses with exotic breeds has led Brazilian creole goats to a process of genetic degeneration. Research on phenotypic and genetic characterization of goats provides information on their situation of risk, as the studies led by Ribeiro et al. (2012), Conrado et al. (2015), and Costa et al. (2016).

Carcass quantitative traits are fundamental in the production process and for the recognition of the importance of goats, as they are directly linked to the end product - the meat (Hashimoto et al., 2012). In this regard, the use of in vivo techniques is advantageous, as it allows of the access to information on carcass and meat-production performance of an animal, without requiring its slaughter (Figueiredo Filho et al., 2012).

Parasitic infections are the main diseases affecting goat herds with losses caused by anorexia, apathy, decreased production, and weight loss in the infected animals (Nery et al., 2010). These infections are a serious problem to small ruminants, representing economic losses to the producers.

Phenotypic markers are associated with the resistance to parasitic infection, and can be used as parameters in selection programs (Bricarello et al.,
2007). By uniting the morphometric measurement, carcass-quality, and data on the resistance to parasites, it can be possible to show to goat producers the relevance of rearing creole goats, ensuring the animal survival and, thereby, making it possible to preserve a source of genetic material capable of increasing the resistance of other breeds to unfavorable conditions in the rearing environment (Mariante et al., 2011).

The maintenance of genetic intra-population diversity is essential to the survival of creole populations. In the case of breeding programs, it ensures the establishment of selection pressure and increases the production (Biagiotti et al., 2014).

The objective of this work was to phenotypically characterize creole goats of the Moxotó, Azul, Canindé, Repartida, Marota, and Graúna breeds, in comparison to Boer, Anglo Nubian, and Alpine exotic breeds, in order to identify the genetic groups of greater potential for carcass quality, and for the resistance to infection by worm.

\section{Materials and Methods}

The experiment was carried out after being approved by the animal experimentation ethics committee of Universidade Federal do Piauí (No. 156/16), at Faveira farm, in the municipality of Elesbão Veloso, in the state of Piauí, Brazil $\left(06^{\circ} 12^{\prime} 07^{\prime \prime} \mathrm{S}, 42^{\circ} 08^{\prime} 25^{\prime \prime} \mathrm{W}\right)$. Visits to the property took place in June 2016, for data collection. A total of 264 goats of the Moxoto (55), Azul (45), Canindé (57), Repartida (40), Marota (30), and Graúna (37) Brazilian creole breeds, plus 44 goats of the Alpine (19), Boer (12), and Anglo Nubian (13) exotic breeds were used in the study, totaling 308 animals aged one to four years. This quantity corresponds to the number of animals in the property, at the time of data collection. Exotic goats were used for comparison and evaluation of the possibility of introgression of these breeds in the local ones. In the farm, the animals were separated by breed in earthen-floor sheds, reared in a semi-intensive system by which they fed on native pasture, and supplemented with corn silage. There was no effective reproduction control, and the sanitary control was achieved with deworming procedures every six months. The amount of vermifuge (not specified by the farmer) was dosed according to the animal age and the manufacturer's instructions. In addition, other medications were applied whenever necessary. 
The counts of worm eggs in the feces (WEGF) were performed using the technique described by Gordon \& Whitlock (1939), which consists of weighing $2.0 \mathrm{~g}$ of feces, diluting them in $48.0 \mathrm{~mL}$ supersaturated table sugar solution, crushing them with a stick, and sieving them. This process was performed so that the fecal suspension was homogenized and, using a pipette, a small amount of the sample was collected to fill a McMaster chamber. Around 2 min after preparation, the eggs were counted using the two sides of the chamber. The microscopic observation was performed with an $8 \mathrm{X}$ ocular and a 10X objective. To determine the degree of infection of the animals, the number of eggs found in the right and left areas were added together, and the total was multiplied by 100 as a function of the proportion of feces examined, by which each counted area of the chamber corresponds to the centesimal part of $1 \mathrm{~g}$ of feces (Ueno \& Gonçalves, 1998).

The Famacha method was employed to determine anemia, based on the color of the ocular conjunctiva (Molento et al., 2004). The examiner exposed the ocular conjunctiva of the animal by pressing the upper eyelid with one of his thumbs and lowering the lower eyelid with the other, allowing of the partial exposure of the internal membrane of the eyelid, and comparing it with the colors on the Famacha eye color chart. Five color degrees are illustrated in the chart, by which degrees 1 and 2 indicate animals with a normal-colored ocular conjunctiva, that is, practically no signs of anemia. Degree 3, in turn, suggests a need for deworming. Degrees 4 and 5 mean deworming is mandatory, since the conjunctiva has an intense paleness. Additionally, degree 5 indicates that the animal must receive dietary supplementation. Famacha eye-score results, coupled with the counts of WEGF, were used to draw inferences on the animal resistance potential to worm infections.

For the carcass evaluation, body condition score (BCS) data were collected by palpating the lumbar region of the animal, which was done by a single observer to prevent any systematic error attributed to the assessment, adopting a scale of 1 to 5 points. The ultrasonographic measurements of loin-eye area (LEA) and loin-eye depth (LED) were taken at a 3/4 distance from the ventral length of the longissimus dorsi muscle, and between the $12^{\text {th }}$ and $13^{\text {th }}$ ribs. Sternal fat thickness (SFT) was measured in the mediastinal region of the third sternebra. Images were analyzed using the Chison Vet 660 instrument equipped with a $3.5-\mathrm{MHz}$ linear transducer. Simultaneously to each collection, the animals were weighed on an analogical scale with capacity for up to $100 \mathrm{~kg}$.

The following body measurements were taken, using a tape measure: wither height $(\mathrm{WH})$, rump height $(\mathrm{RH})$, body length (BL), ear length (EL), thoracic circumference (TC), and brisket height (BH).

Statistical analyses were carried out using the $\mathrm{R}$ Core Team software, version 3.3.1 (R Core Team, 2016). Analyses of mean, standard deviation, and coefficient of variation, as well as analysis of variance, were conducted with the morphometric measurements WH, RH, BL, BH, TC, and EL; carcass measurements LEA, LED, SFT, and BCS; body weight (BW); WEGF; and Famacha eye score. Data were compared by the SNK test, at $5 \%$ probability. The Pearson correlation coefficients were calculated to determine the association among LEA, LED, SFT, BCS, and BW, and among WEGF, Famacha score, BCS, and BW.

For the study on diversity, a cluster analysis was performed, adopting the mean Euclidian distance as a measure of dissimilarity between breeds, using the single linkage, average linkage, or unweighted pairgroup method with arithmetic mean (UPGMA), and complete linkage methods, establishing dendrograms with groups of greater phenotypic similarity, according to Everitt et al. (2011). A bootstrap was run with 1,000 resamplings of the dendrogram, to provide the percentage of replicates similar to the original data that could explain the clusters that showed a reliability value of over $50 \%$. For the adequate choice of the cluster method, the cophenetic correlation coefficient was calculated according to Sokal \& Rohlf (1962).

\section{Results and Discussion}

Mean values for the body measurements of creole and exotic goats are shown in Table 1. Regarding size, Repartida animals showed the highest mean for wither height $(61.55 \mathrm{~cm})$, rump height $(62.16$ $\mathrm{cm})$, and body length $(71.46 \mathrm{~cm})$, and no significant difference was recorded for the other local breeds. Among the Brazilian creole goats, the highest thoracic circumference value $(62.07 \mathrm{~cm})$ was found in Canindé breed. These results indicate larger and more robust animals among the evaluated individuals. As to thoracic circumference, Almeida (2007) stated that a greater thoracic development directly leads to a better respiratory capacity and dry matter intake,

Pesq. agropec. bras., Brasília, v.53, n.7, p.849-857, July 2018 DOI: 10.1590/S0100-204X2018000700009 
which ultimately improves the productive yield of the animal. The three exotic breeds showed no significant differences for wither height and rump height; thoracic circumference differed between the Alpine and Boer breeds; and body length was similar for the Alpine and Anglo Nubian goats.

Among the creole breeds, the Moxoto showed the highest ear length $(13.45 \mathrm{~cm})$, which differs from the results found by Rocha et al. (2007), who studied the same breed in the states of Paraíba, Pernambuco, and Rio Grande do Norte, Brazil. These authors observed the highest mean for ear length $(13.77 \mathrm{~cm})$ in the state of Paraíba, and the lowest one was observed in the state of Pernambuco $(11.56 \mathrm{~cm})$. This finding may be a consequence of crosses with exotic breeds, which leads us to suppose that the ear size is also a way to identify miscegenation of creole goats with exotic breeds (Nascimento, 2010). Ear length did not differ between the Anglo Nubian and Boer breeds, whose means were $19.73 \mathrm{~cm}$ and $19.83 \mathrm{~cm}$, respectively. However, between these two breeds and the Alpine, mean ear length values were significant.

The highest brisket height value $(36.37 \mathrm{~cm})$ was found in Canindé goats; a significant difference was detected between the means of Graúna $(32.08 \mathrm{~cm})$ and Marota $(30.38 \mathrm{~cm})$ goats. The exotic goats with longest legs were the Anglo Nubian $(37.50 \mathrm{~cm})$ and Alpine $(34.89 \mathrm{~cm})$, with nonsignificant means, and the Boer breed $(34.75 \mathrm{~cm})$, which in comparison with the other two, showed a significant result. There was no significant difference for brisket height among the Canindé, Alpine, Anglo Nubian, and Boer breeds. The lower brisket height means confirm the theory defended by Hafez (1973), that meat-specialized breeds have shorter and thicker bones, and a thicker musculature, originating shorter extremities.

In the carcass evaluation, the highest means for all traits measured in the exotic goats were obtained by Boer breed animals (Table 2). According to Pereira Filho et al. (2008), these animals stand out for their excellent conformation and rapid growth. For the Alpine and Anglo Nubian goats, the means of all traits showed nonsignificant results. Among the Brazilian indigenous goats, the highest mean of LEA $\left(5.63 \mathrm{~cm}^{2}\right)$ was measured in the Moxotó breed, and the lowest one $\left(3.47 \mathrm{~cm}^{2}\right)$, in the Marota breed. Body weight ranged from $24.35 \mathrm{~kg}$, for the Azul goats, to $30.35 \mathrm{~kg}$, for animals of the Moxotó breed. In the words of Lima Neto et al. (2009), an increase of body weight increases the longissimus dorsi muscle area; agreeing with this information, we observed that the Moxoto breed, which displayed the highest mean for LEA, also had the highest-body weight. Among the exotic breeds, the Boer animals showed the largest LEA $\left(6.64 \mathrm{~cm}^{2}\right)$ and, consequently, this breed showed the heaviest body weight $(52.00 \mathrm{~kg})$.

The highest mean LED was found in the Moxotó breed $(1.67 \mathrm{~cm})$, and the lowest one in the Graúna goats

Table 1. Means and standard deviations for wither height (WH), rump height (RH), brisket height (BH), thoracic circumference (TC), body length (BL), and ear length (EL) of the Brazilian creole goat breeds - Canindé, Moxotó, Azul, Repartida, Graúna, and Marota -, as well as of the Anglo Nubian, Boer, and Alpine exotic breeds ${ }^{(1)}$.

\begin{tabular}{|c|c|c|c|c|c|c|}
\hline \multirow[t]{2}{*}{ Goat } & \multicolumn{6}{|c|}{ Parameter $(\mathrm{cm})$} \\
\hline & $\begin{array}{l}\text { Wither } \\
\text { height }\end{array}$ & $\begin{array}{l}\text { Rump } \\
\text { height }\end{array}$ & $\begin{array}{l}\text { Brisket } \\
\text { height }\end{array}$ & $\begin{array}{c}\text { Thoracic } \\
\text { circumference }\end{array}$ & $\begin{array}{l}\text { Body } \\
\text { length }\end{array}$ & $\begin{array}{c}\text { Ear } \\
\text { length }\end{array}$ \\
\hline & \multicolumn{6}{|c|}{ Creole } \\
\hline Canindé & $60.87 \pm 5.15 b$ & $61.19 \pm 5.30 \mathrm{~b}$ & $36.37 \pm 8.8 \mathrm{ab}$ & $62.07 \pm 5.78 \mathrm{~cd}$ & $70.22 \pm 6.30 \mathrm{bc}$ & $12.92 \pm 1.07 \mathrm{~b}$ \\
\hline Moxotó & $59.12 \pm 6.42 b$ & $59.01 \pm 6.17 \mathrm{~b}$ & $32.36 \pm 3.80 \mathrm{bcd}$ & $57.76 \pm 7.10 \mathrm{~d}$ & $66.25 \pm 6.97 \mathrm{c}$ & $13.45 \pm 1.18 \mathrm{~b}$ \\
\hline Azul & $59.37 \pm 5.38 b$ & $59.54 \pm 6.81 b$ & $32.72 \pm 2.95 \mathrm{bcd}$ & $58.58 \pm 5.96 \mathrm{~d}$ & $66.08 \pm 6.02 \mathrm{c}$ & $13.27 \pm 1.05 b$ \\
\hline Repartida & $61.55 \pm 5.44 b$ & $62.16 \pm 5.43 b$ & $32.56 \pm 3.30 \mathrm{bcd}$ & $60.83 \pm 5.55 \mathrm{~cd}$ & $71.46 \pm 6.93 b c$ & $13.09 \pm 1.09 \mathrm{~b}$ \\
\hline Graúna & $59.51 \pm 5.21 \mathrm{~b}$ & $59.75 \pm 4.95 b$ & $32.08 \pm 4.52 \mathrm{~cd}$ & $62.00 \pm 6.86 \mathrm{~cd}$ & $70.20 \pm 7.28 b c$ & $13.10 \pm 1.17 \mathrm{~b}$ \\
\hline \multirow[t]{2}{*}{ Marota } & $58.09 \pm 5.35 \mathrm{~b}$ & $58.67 \pm 6.35 \mathrm{~b}$ & $30.38 \pm 3.87 \mathrm{~d}$ & $59.40 \pm 7.20 \mathrm{~cd}$ & $69.95 \pm 8.01 \mathrm{c}$ & $13.27 \pm 1.93 b$ \\
\hline & \multicolumn{6}{|c|}{ Exotic } \\
\hline Alpine & $65.81 \pm 4.65 \mathrm{a}$ & $67.05 \pm 3.73 \mathrm{a}$ & $34.89 \pm 3.57 \mathrm{abc}$ & $64.78 \pm 7.87 b$ & $76.10 \pm 5.27 \mathrm{~b}$ & $12.65 \pm 0.98 b$ \\
\hline Anglo Nubian & $67.46 \pm 5.23 \mathrm{a}$ & $68.08 \pm 4.85 \mathrm{a}$ & $37.50 \pm 3.25 \mathrm{a}$ & $64.08 \pm 6.80 \mathrm{bc}$ & $74.92 \pm 6.40 \mathrm{~b}$ & $19.73 \pm 2.19 \mathrm{a}$ \\
\hline Boer & $66.33 \pm 4.51 \mathrm{a}$ & $66.66 \pm 4.45 \mathrm{a}$ & $34.75 \pm 2.13 \mathrm{abc}$ & $69.58 \pm 6.21 \mathrm{a}$ & $81.83 \pm 6.57 \mathrm{a}$ & $19.83 \pm 1.85 \mathrm{a}$ \\
\hline Coefficient of variation (\%) & 8.97 & 9.28 & 15.03 & 9.87 & 10.38 & 9.55 \\
\hline
\end{tabular}

${ }^{(1)}$ Means followed by equal letters, in the columns, do not differ significantly by the SNK test, at $5 \%$ probability. CV, coefficient of variation. 
$(1.29 \mathrm{~cm})$, with no significant differences. Just as LEA, LED indicates muscularity in the carcass. Among the exotic breeds, the highest LED was observed in the Boer animals $(1.98 \mathrm{~cm})$. No difference was detected for SFT between the mean values of the Anglo Nubian and Alpine goats, while the Boer breed showed the highest SFT mean $(4.10 \mathrm{~mm})$. The highest deposition of fat in the sternal region was found in the Moxoto breed animals, with $3.77 \mathrm{~mm}$; in comparison with the Marota breed $(2.89 \mathrm{~mm})$, this value showed a significant difference.

According to Shittu et al. (2014), healthy goats are expected to be in a BCS range of 2 to 3.5 points. In the present study, BCS was on average 2.59 points for Canindé and Repartida animals, and up to 3.11 for the Moxotó breed. Animals of the Boer breed showed the highest BCS value (3.45 points), and, among the creole breeds, Moxotó stood out, as previously stated.

Based on the scale established by Ueno \& Gonçalves (1998), the degree of infection was mild, with highest average value of 700 among the nine herds. On the basis of this scale, and considering the rearing system to which the animals were subjected to, we can infer that there was no possibility of distinction between resistant or susceptible animals, probably because of the low risks of infection, which did not promote adequate conditions for the life cycle of parasites.

As shown in Table 3, there was no significant difference for average WEGF among the creole goats. The highest mean for WEGF was observed in Azul breed animals with 146.34 eggs $\mathrm{g}^{-1}$ feces - eggs per gram of feces (EPG), with a maximum observed value of $700 \mathrm{EPG}$, while the lowest average was 47.22 EPG for Repartida goats, whose maximum value was 200 EPG. The Canindé, Marota, and Graúna breeds displayed respective WEGF means of 50.98, 85.18, and $84.37 \mathrm{EPG}$, all of which had a maximum count of 400 EPG among the individuals. The Moxotó animals averaged 87.75, with a maximum count of 600 EPG. We observed that although the animals were reared under the same management conditions, they showed different parasitic loads, which was also observed by Sotomaior et al. (2007). Among the exotic breeds, no significant difference was observed either. Alpine goats had the lowest maximum WEGF value (100 EPG), averaging 27.77. The Anglo Nubian and Boer goats obtained a maximum WEGF of 200 EPG, averaging 16.66 and 33.33 EPG, respectively.

The average Famacha eye score was 2.77, which is similar to the findings of Cavele (2009). In the presenty study, the lowest mean value for this variable was found in the Marota breed animals (2.59), and the highest one, for the Graúna goats (3.18). The results for exotic breeds were 3.0 for Boer, 2.61 for Alpine, and 2.66 for Anglo Nubian. Azul goats had a Famacha score of 2.73; Moxotó and Repartida, 2.61; and Canindé, 2.94. Sotomaior et al. (2007) stated that the classification using Famacha score data may represent both resistant animals (when their immune response limits the establishment of the parasite), and resilient

Table 2. Means and standard deviations for loin-eye area (LEA), loin-eye depth (LED), sternal fat thickness (SFT), body condition score (BCS), and body weight (BW) of the Brazilian creole goat breeds - Canindé, Moxotó, Azul, Repartida, Graúna, and Marota -, as well as of the Alpine, Anglo Nubian, and Boer exotic breeds ${ }^{(1)}$.

\begin{tabular}{|c|c|c|c|c|c|}
\hline \multirow[t]{2}{*}{ Goat } & \multicolumn{5}{|c|}{ Parameter } \\
\hline & $\operatorname{LEA}\left(\mathrm{cm}^{2}\right)$ & LED (cm) & SFT (mm) & BCS (points) & $\mathrm{BW}(\mathrm{kg})$ \\
\hline \multicolumn{6}{|c|}{ Creole } \\
\hline Canindé & $4.50 \pm 1.02 \mathrm{c}$ & $1.53 \pm 0.25 \mathrm{bc}$ & $3.73 \pm 0.88 \mathrm{ab}$ & $2.59 \pm 0.76 b c$ & $29.31 \pm 7.87 \mathrm{~cd}$ \\
\hline Moxotó & $5.63 \pm 1.72 b$ & $1.67 \pm 0.39 b$ & $3.77 \pm 0.90 \mathrm{ab}$ & $3.11 \pm 0.56 \mathrm{ab}$ & $30.35 \pm 5.88 \mathrm{~cd}$ \\
\hline Azul & $4.62 \pm 1.28 \mathrm{c}$ & $1.50 \pm 0.30 \mathrm{bc}$ & $3.39 \pm 0.67 \mathrm{bc}$ & $2.70 \pm 0.60 b c$ & $24.35 \pm 5.60 \mathrm{~d}$ \\
\hline Repartida & $3.82 \pm 0.98 \mathrm{c}$ & $1.35 \pm 0.22 \mathrm{c}$ & $4.38 \pm 0.64 \mathrm{a}$ & $2.59 \pm 0.55 b c$ & $27.77 \pm 7.21 \mathrm{~d}$ \\
\hline Graúna & $4.04 \pm 1.28 \mathrm{c}$ & $1.29 \pm 0.28 \mathrm{c}$ & $4.48 \pm 1.05 \mathrm{a}$ & $2.62 \pm 0.54 \mathrm{bc}$ & $28.93 \pm 7.82 \mathrm{~cd}$ \\
\hline Marota & $3.47 \pm 1.23 \mathrm{c}$ & $1.33 \pm 0.32 \mathrm{c}$ & $2.89 \pm 0.72 \mathrm{~cd}$ & $2.70 \pm 0.62 \mathrm{bc}$ & $24.80 \pm 8.33 \mathrm{~d}$ \\
\hline \multicolumn{6}{|c|}{ Exotic } \\
\hline Alpine & $3.90 \pm 0.85 c$ & $1.41 \pm 0.16 \mathrm{bc}$ & $2.71 \pm 0.58 \mathrm{~d}$ & $2.70 \pm 0.68 \mathrm{bc}$ & $37.25 \pm 9.74 b$ \\
\hline Anglo Nubian & $3.65 \pm 1.32 \mathrm{c}$ & $1.55 \pm 0.28 b c$ & $2.33 \pm 0.45 \mathrm{~d}$ & $2.16 \pm 1.08 \mathrm{c}$ & $34.44 \pm 5.68 \mathrm{bc}$ \\
\hline Boer & $6.64 \pm 1.43 \mathrm{a}$ & $1.98 \pm 0.27 \mathrm{a}$ & $4.10 \pm 0.89 a$ & $3.45 \pm 0.43 \mathrm{a}$ & $52.00 \pm 7.68 \mathrm{a}$ \\
\hline Coefficient of variation $(\%)$ & 28.56 & 19.89 & 22.16 & 23.48 & 24.53 \\
\hline
\end{tabular}

${ }^{(1)}$ Means followed by equal letters, in the columns, do not differ significantly by the SNK test, at $5 \%$ probability. CV, coefficient of variation. 
animals (when they coexist with the parasites, but have a minimal decrease of productivity). Moreover, resistance to parasites is an inheritable trait, which makes it ideal to select less susceptible animals to compose future herds.

Correlations among Famacha eye score, WEGF, BCS, and body weight are presented in Table 4. No correlation was observed between Famacha score and WEGF, whose results differed from those found by Abrão et al. (2010), which were of low magnitude. Those authors stated that this occurs when nutrition plays a part in the response to gastrointestinal parasitism, and when there is parasitic load by Haemoncus contortus. However, Sotomaior et al. (2007) stated that there is no direct correlation between WEGF data and the classification given by the Famacha method. Our results were similar to those reported in the study of Salgado (2011), in which although Haemoncus contortus was the predominating parasite, the elevated parasitic load of nematodes of the genus Trichostrongylus sp. might have contributed to the increase of the number of eggs per gram of feces, and to the lack of increase of Famacha eye score, since these parasites are not hematophagous.

The use of BCS associated with the Famacha method is a viable alternative to improve the accuracy of the clinical evaluation of animals for a selective treatment (Rosalinski-Moraes et al., 2012). The correlation

Table 3. Means, standard deviations, and coefficients of variation (CV) for the counts of worm egg in feces (WEGF) and Famacha eye score of the Brazilian creole goat breeds - Canindé, Moxotó, Azul, Repartida, Graúna, and Marota -, as well as of the Anglo Nubian, Boer, and Alpine exotic breeds $^{(1)}$.

\begin{tabular}{lcc}
\hline Goat & WEGF & Famacha \\
\hline \multicolumn{3}{c}{ Creole } \\
Canindé & $50.98 \pm 92.46 \mathrm{ab}$ & $2.94 \pm 0.94 \mathrm{a}$ \\
Moxotó & $87.75 \pm 148.08 \mathrm{ab}$ & $2.61 \pm 0.93 \mathrm{a}$ \\
Azul & $146.34 \pm 185.87 \mathrm{a}$ & $2.73 \pm 0.77 \mathrm{a}$ \\
Repartida & $47.22 \pm 84.46 \mathrm{ab}$ & $2.61 \pm 0.76 \mathrm{a}$ \\
Graúna & $84.37 \pm 124.71 \mathrm{ab}$ & $3.18 \pm 0.78 \mathrm{a}$ \\
Marota & $85.18 \pm 113.35 \mathrm{ab}$ & $2.59 \pm 0.69 \mathrm{a}$ \\
\hline \multicolumn{3}{c}{ Exotic } \\
Alpine & $27.77 \pm 46.08 \mathrm{~b}$ & $2.61 \pm 0.77 \mathrm{a}$ \\
Anglo Nubian & $16.66 \pm 57.73 \mathrm{~b}$ & $2.66 \pm 0.65 \mathrm{a}$ \\
Boer & $33.33 \pm 70.71 \mathrm{~b}$ & $3.00 \pm 0.86 \mathrm{a}$ \\
\hline CV (\%) & 169.49 & 30.41 \\
\hline
\end{tabular}

${ }^{(1)}$ Means followed by equal letters, in the columns, do not differ significantly by the SNK test, at $5 \%$ probability. $\mathrm{CV}$, coefficient of variation. between Famacha eye score and BCS was low and negative (-0.24), indicating that, at a low magnitude, animals with a better body condition showed the lowest Famacha score. A low correlation was also observed between Famacha eye score and BW (0.16). The correlation was also low (0.12) between WEGF and BCS, and the animals with best BCS obtained the lowest degree of parasitic infection, with a negative and low correlation between WEGF and body weight $(-0.18)$. Both body condition score and body weight can represent the nutritional status of an animal; therefore, animals with better nutritional responses may show a lower degree of infection and, possibly, lower WEGF values. Although the correlation between BCS and body weight was low (0.19), heavier goats showed the best $\mathrm{BCS}$ values.

The correlation between the carcass measurements LEA and LED - which are considered direct representatives of muscularity - was positive and moderate (0.61) (Table 5). With BCS and body weight, however, LEA had a relatively low correlation. There was a negative, low correlation between SFT and BCS $(-0.31)$, suggesting that despite showing a higher-body condition score, animals tended to have a less fat deposition in the sternal region. Working with goats, Figueiredo Filho et al. (2012) reported that an increase of carcass muscularity is normally accompanied by fat deposition in the sternal region at a medium magnitude,

Table 4. Pearson correlation among Famacha eye score, counts of worm egg in feces (WEGF), body condition score (BCS), and body weight (BW) of exotic and creole goat breeds.

\begin{tabular}{lcccc}
\hline & Famacha & WEGF & BCS & BW \\
\hline Famacha & 1.00 & -0.07 & -0.24 & 0.16 \\
WEGF & & 1.00 & 0.12 & -0.18 \\
BCS & & & 1.00 & 0.19 \\
BW & & & & 1.00 \\
\hline
\end{tabular}

Table 5. Pearson correlation among loin-eye area (LEA), loin-eye depth (LED), sternal fat thickness (SFT), body condition score (BCS), and body weight (BW) of exotic and creole goat breeds.

\begin{tabular}{|c|c|c|c|c|c|}
\hline & LEA & LED & SFT & BCS & BW \\
\hline LEA & & 0.61 & 0.19 & 0.46 & 0.47 \\
\hline LED & & & 0.14 & 0.26 & 0.41 \\
\hline SFT & & & & -0.31 & 0.14 \\
\hline BCS & & & & & 0.30 \\
\hline
\end{tabular}


since this location is the main subcutaneous fat depot in goats.

Body weight and sternal fat thickness are correlated at a low magnitude, that is, lower-animal weights mean a lower SFT. At adult age, higher weights will correspond (in moderate proportions) to a better nutritional status of the animal, as assessed by the visual scores, corroborating the literature results (Barbosa et al., 2009). The correlations of LEA and LED with BW were moderate and positive, indicating that heavier animals have typically a greater loin-eye area and depth.

Dendrograms were generated based on the shortest distance of the morphometric traits wither height, rump height, brisket height, body length, thoracic circumference, and ear length, in which bootstrap values greater than $50 \%$ showed reliability in the formation of nodes (Figure 1). Although the general structure of the clusters was similar, there were slight alterations in the levels at which the individuals are grouped, that is, those within the same group may be clustered in another order when the clustering methods are changed.

Only the single-linkage method had the Boer breed separated into another group, but without much consistency, as it showed a bootstrap value of only $44.0 \%$. The single-linkage clustering method (Figure $1 \mathrm{~A}$ ) led to a greater differentiation when compared by UPGMA (Figure 1 B) and complete linkage (Figure $1 \mathrm{C}$ ). The latter two, in turn, grouped the local breeds in a separate cluster from the Boer, Alpine, and Anglo Nubian exotic breeds.

Irrespective of the method, the Azul and Moxotó goats remained in the same subgroup, with consistent $96.0 \%$ bootstraps. These animals did not show significant differences between the morphometric measurements and may, thus, be selected from them. Another hypothesis is that these animals may have ancestors in common, as over years they have undergone evolution processes and natural selection, acquiring similar morphometric traits. With the cophenetic correlation results for each one of the methods, UPGMA had the highest value (0.88) and, therefore, it was the most suitable method to summarize the information of the dataset.

The clusters obtained for the carcass traits show that, in the three methods, the Boer breed formed a separate cluster from the others (Figure 2). This breed had the highest values for the obtained means. The three methods had the breeds divided into two groups: the first one contained the Boer breed, which, according to the obtained means, showed the highest values; and the second group included the other breeds, with a bootstrap of $74 \%$ by the single-linkage method
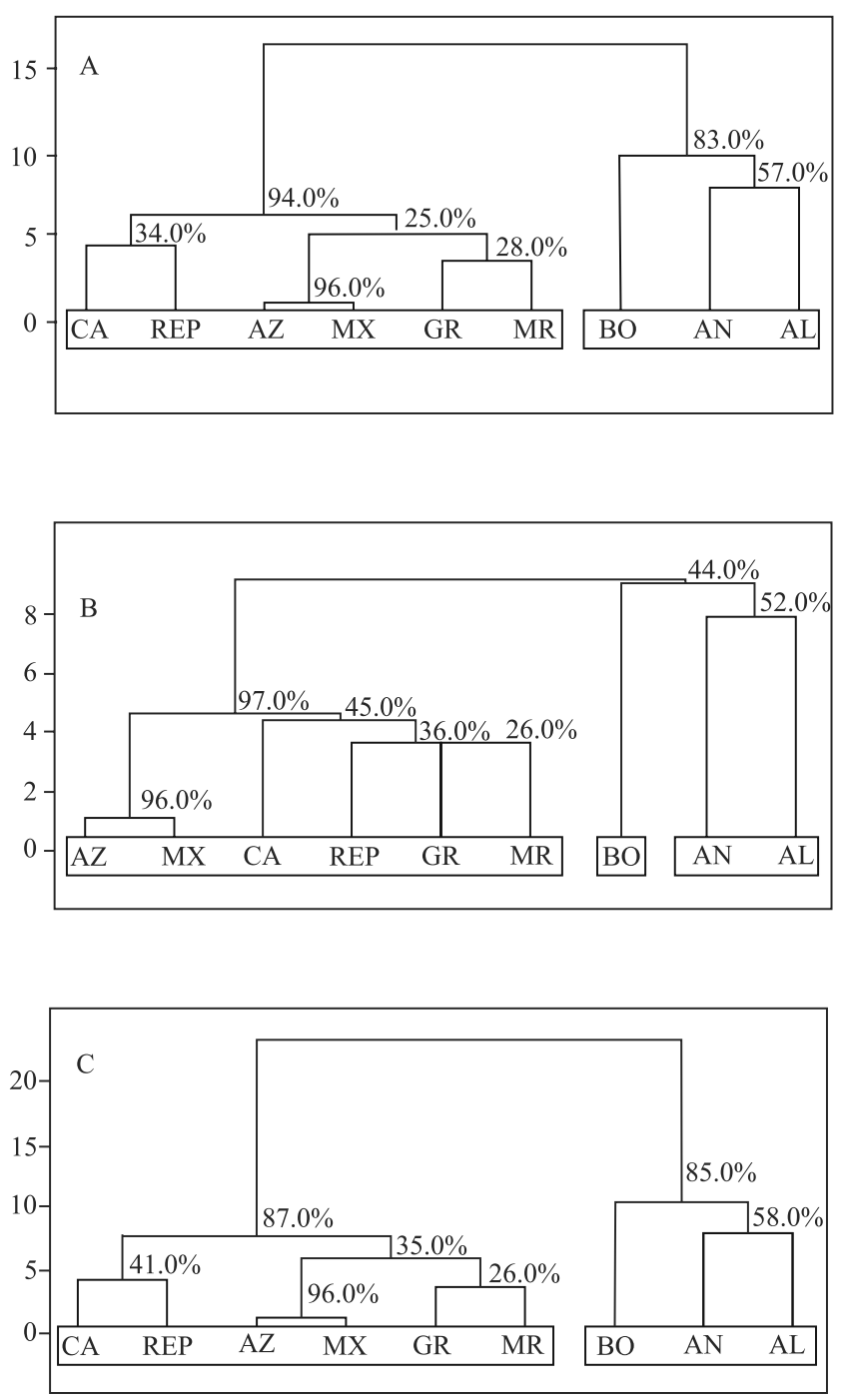

Figure 1. Dendrograms based on the mean Euclidian distance among the Boer (BO), Anglo Nubian (AN), Alpine (AL), Marota (MR), Graúna (GR), Repartida (REP), Moxotó (MX), Azul (AZ), and Canindé (CA) goat breeds. Single-linkage (A), unweighted pair-group method with arithmetic mean (B), and complete-linkage (C) methods for the following morphometric measurements: wither height (WH), rump height $(\mathrm{RH})$, body length $(\mathrm{BL})$, thoracic circumference (TC), brisket height $(\mathrm{BH})$, and ear length (EL). 
(Figure 2 A), $68 \%$ by UPGMA (Figure 2 B), and $69 \%$ by the complete-linkage method (Figure $2 \mathrm{C}$ ). As occurred for the morphometric traits, the UPGMA obtained from the carcass measurements had the highest cophenetic correlation coefficient (0.95), and was the best solution for the structuring of the clusters.
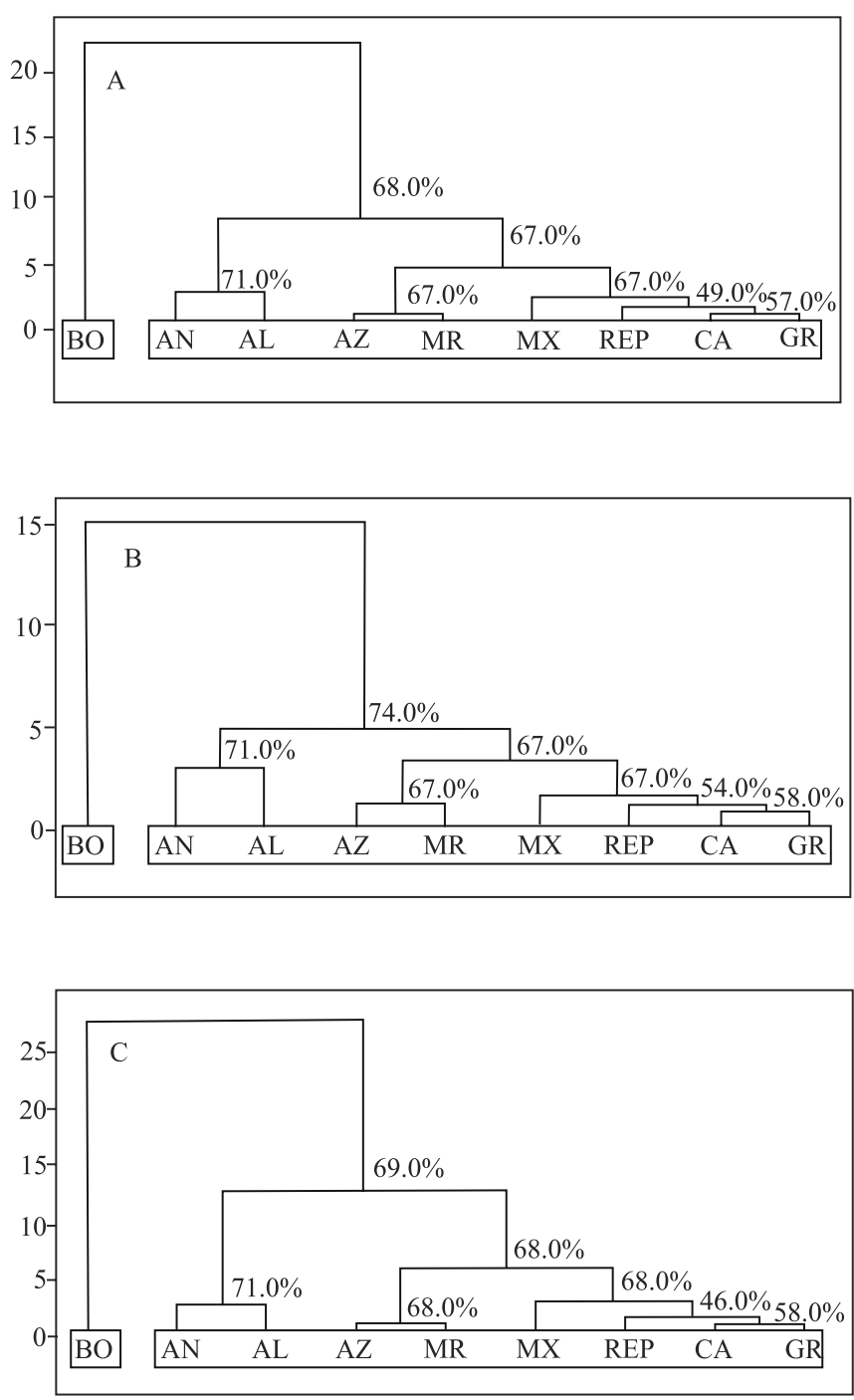

Figure 2. Dendrograms based on the mean Euclidian distance among the Boer (BO), Anglo Nubian (AN), Alpine (AL), Marota (MR), Graúna (GR), Repartida (REP), Moxotó (MX), Azul (AZ), and Canindé (CA) goat breeds. Singlelinkage (A), unweighted pair-group method with arithmetic mean (B), and complete-linkage (C) methods based on loineye area (LEA), loin-eye depth (LED), sternal fat thickness (SFT), body condition score (BCS), and body weight (BW).

\section{Conclusions}

1. The use of morphometric and carcass measurements shows satisfactory results for the phenotypic characterization of Brazilian creole goats.

2 . The genetic groups of Brazilian creole goats can be indicated for genetic conservation and breeding programs, for both their resistance to worm infections and their high-quality carcass traits.

\section{Acknowledgments}

To Coordenação de Aperfeiçoamento de Pessoal de Nível Superior (Capes), to Universidade Federal do Piauí (UFPI), to Grupo de Estudos em Melhoramento Animal (GEMA), and to the owner of Faveira Farm, Mr. José Dantas, for the support.

\section{References}

ABRÃO, D.C.; ABRÃO, S.; VIANA, C.H.C.; VALLE, C.R. do. Utilização do método Famacha no diagnóstico clínico individual de haemoncose em ovinos no Sudoeste do Estado de Minas Gerais. Revista Brasileira de Parasitologia Veterinária, v.19, p.68-70, 2010. DOI: 10.1590/S1984-29612010000100014.

ALMEIDA, M.J.O. de. Caracterização de caprinos da raça Marota no Brasil. 2007. 128p. Tese (Doutorado) - Universidade Federal da Paraíba, Areia.

BARBOSA, L.P.; RODRIGUES, M.T.; GUIMARÃES, J.D.; MAFFILI, V.V.; AMORIM, L. da S.; GARCEZ NETO, A.F. Condição corporal e desempenho produtivo de cabras Alpinas no início de lactação. Revista Brasileira de Zootecnia, v.38, p.21372143, 2009. DOI: 10.1590/S1516-35982009001100010.

BIAGIOTTI, D.; GUIMARÃES, F.F.; SARMENTO, J.L.R.; SANTOS, G.V. dos; REGO NETO, A.A. do; SANTOS, N.P. da S.; SARAIVA, T.T.; FIGUEIREDO FILHO, L.A.S.; SENA, L.S. Uso de estatística multivariada para estudo de caracterização racial em ovinos. Acta Tecnológica, v.9, p.16-26, 2014.

BRICARELLO, P.A.; ZAROS, L.G.; COUTINHO, L.L.; ROCHA, R.A.; KOOYMAN, F.N.J.; DE VRIES, E.; GONÇALVES, J.R.S.; LIMA, L.G.; PIRES, A.V.; AMARANTE, A.F.T. Field study on nematode resistance in Nelore-breed cattle. Veterinary Parasitology, v.148, p.272-278, 2007. DOI: 10.1016/j. vetpar.2007.06.013.

CAVELE, A. Variáveis clínica, parasitológica, hematológica e bioquímica de caprinos e ovinos infectados naturalmente por nematóides gastrintestinais sob o mesmo sistema de produção. 2009. 85p. Dissertação (Mestrado) - Universidade Federal da Bahia, Salvador.

CONRADO, V.D.C.; ARANDAS, J.K.G.; RIBEIRO, M.N. Modelos de regressão para predição do peso da raça Canindé através de medidas morfométricas. Archivos de Zootecnia, v.64, p.277-280, 2015. DOI: 10.21071/az.v64i247.400. 
COSTA, M. da S.; ARAÚJO, A.M. de; CAMPELOM, J.E.G.; MACHADO, T.M.M.; PIRES, L.C.; EGITO, A.A. do; MARIANTE, A. da S. Inventário e caracterização morfológica de caprinos Gurgueia no Estado do Piauí. Revista Brasileira de Saúde e Produção Animal, v.17, p.127-138, 2016. DOI: 10.1590/ S1519-99402016000200001.

EVERITT, B.S.; LANDAU, S.; LEESE, M.; STAHL, D. Cluster analysis. $5^{\text {th }}$ ed. London: J. Wiley \& Sons, 2011. 337p. DOI: 10.1002/9780470977811.

FIGUEIREDO FILHO, L.A.S.; SARMENTO, J.L.R.; CAMPELO, J.E.G.; SANTOS, N.P. da S.; SOUSA JÚNIOR, A. Medidas de características da carcaça por meio de ultrassonografia em caprinos. Revista Brasileira de Saúde e Produção Animal, v.13, p.804-814, 2012. DOI: 10.1590/S1519-99402012000300018.

GORDON, H.M.; WHITLOCK, H.V. A new technique for counting nematode eggs in sheep faeces. Journal of the Council for Scientific and Industrial Research, v.12, p.50-52, 1939.

HAFEZ, E.S.E. Adaptación de los animales domesticos. Barcelona: Labor, 1973. 563p.

HASHIMOTO, J.H.; OSÓRIO, J.C. da S.; OSÓRIO, M.T.M.; BONACINA, M.S.; LEHMEN, R.I.; PEDROSO, C.E. da S. Qualidade da carcaça, desenvolvimento regional e tecidual de cordeiros terminados em três sistemas. Revista Brasileira de Zootecnia, v.41, p.438-448, 2012. DOI: 10.1590/S151635982012000200029 .

LIMA NETO, H.R.; BERGMANN, J.A.G.; GONÇALVES, T.M.; ARAÚJO, F.R.C.; BEZERRA, L.A.F.; SAIZ, R.D.; LÔBO, R.B.; SILVA, M.A. Parâmetros genéticos para características de carcaça avaliadas por ultrassonografia em bovinos da raça Guzerá. Arquivo Brasileiro de Medicina Veterinária e Zootecnia, v.61, p.251-258, 2009. DOI: 10.1590/S010209352009000100035.

MARIANTE, A. da S.; ALBUQUERQUE, M. do S.M.; RAMOS, A.F. Criopreservação de recursos genéticos animais brasileiros. Revista Brasileira de Reprodução Animal, v.35, p.64-68, 2011.

MOLENTO, M.B.; TASCA, C.; GALLO, A.; FERREIRA, M.; BONONI, R.; STECCA, E. Método Famacha como parâmetro clínico individual de infecção por Haemonchus contortus em pequenos ruminantes. Ciência Rural, v.34, p.1139-1145, 2004. DOI: $10.1590 / \mathrm{S} 0103-84782004000400027$.

NASCIMENTO, R. de B. Caracterização morfoestrutural e do sistema de criação da raça Moxotó em seu centro de origem com base no conhecimento local. 2010. 75p. Dissertação (Mestrado) - Universidade Federal Rural de Pernambuco, Recife.

NERY, P.S.; NOGUEIRA, F.A.; MARTINS, E.R.; DUARTE, E.R. Effects of Anacardium humile leaf extracts on the development of gastrointestinal nematode larvae of sheep. Veterinary Parasitology, v.171, p.361-364, 2010. DOI: 10.1016/j. vetpar.2010.03.043.

PEREIRA FILHO, J.M.; RESENDE, K.T. de; TEIXEIRA, I.A.M. de A.; SILVA SOBRINHO, A.G. da; YÁÑEZ, E.A.; FERREIRA,
Â.C.D. Características de carcaça e alometria dos tecidos de cabritos F1 Boer x Saanen. Revista Brasileira de Zootecnia, v.37, p.905-912, 2008. DOI: 10.1590/S1516-35982008000500019.

PIRES, L.C.; MACHADO T.M.M.; CARNEIRO, P.L.S.; SILVA, J.B.L. da; BARBOSA, A.D. de H.; TORRES, R. de A. Growth curve of Repartida goats reared in the Caatinga region, Brazil. Semina: Ciências Agrárias, v.38, p.1041-1050, 2017. DOI: $10.5433 / 1679-0359.2017 \mathrm{v} 38 \mathrm{n} 2 \mathrm{p} 1041$.

PRODUÇÃO DA PECUÁRIA MUNICIPAL 2015. Rio de Janeiro: IBGE, v.43, 2015. Available at: <http://biblioteca.ibge.gov.br/ visualizacao/periodicos/84/ppm_2015_v43_br.pdf $>$. Accessed on: Jul. 102017.

R CORE TEAM. R: A language and environment for statistical computing. Vienna: R Foundation for Statistical Computing, 2016. RIBEIRO, M.N.; BRUNO-DE-SOUSA, C.; MARTINEZMARTINEZ, A.; GINJA, C.; MENEZES, M.P.C.; PIMENTAFILHO, E.C.; DELGADO, J.V.; GAMA, L.T. Drift across the Atlantic: genetic differentiation and population structure in Brazilian and Portuguese native goat breeds. Journal of Animal Breeding and Genetics, v.129, p.79-87, 2012. DOI: 10.1111/j.14390388.2011.00942.x.

ROCHA, L.L. da; BENÍCIO, R.C.; OLIVEIRA, J.C.V.; RIBEIRO, M.N.; DELGADO, J.V. Avaliação morfoestutural de caprinos da raça Moxotó. Archivos de Zootecnia, v.56, p.483-488, 2007. Suplemento 1.

ROSALINSKI-MORAES, F.; FERNANDES, F.G.; MUNARETTO, A.; DE OLIVEIRA, S.; WILMSEN, M.O.; PEREIRA, M.W.; MEIRELLES, A.C.F. Método FAMACHA, escore corporal e de diarreia como indicadores de tratamento anti-helmíntico seletivo de ovelhas em reprodução. Bioscience Journal, v.28, p.1015-1023, 2012.

SALGADO, J.A. Sistema de produção de cordeiros e seu efeito na infecção por helmintos gastrintestinais. 2011. 66p. Dissertação (Mestrado) - Universidade Federal do Paraná, Curitiba.

SHITTU, A.; ZAHARADEEN, M.M.; FASINA, F.O.; UMARU, M.A.; AHMED, A. Classification of slaughtered animals and estimation of body condition scores during rainy season in Sokoto abattoir. Sokoto Journal of Veterinary Sciences, v.12, p.31-40, 2014.

SOKAL, R.R.; ROHLF, F.J. The comparison of dendrograms by objective methods. Taxon, v.11, p.33-40, 1962. DOI: 10.2307/1217208.

SOTOMAIOR, C.S.; DE CARLI, L.M.; TANGLEICA, L.; KAIBER, B.K.; SOUZA, F.P. de. Identificação de ovinos e caprinos resistentes e susceptíveis aos helmintos gastrintestinais. Revista Acadêmica: Ciência Animal, v.5, p.397-412, 2007. DOI: 10.7213/ cienciaanimal.v5i4.10202.

UENO, H.; GONÇALVES, P.C. Manual para diagnóstico das helmintoses de ruminantes. 4.ed. Tokyo: Japan International Cooperation Agency, 1998. 145p.

Received on May 3, 2017 and accepted on October 4, 2017

Pesq. agropec. bras., Brasília, v.53, n.7, p.849-857, July 2018 DOI: $10.1590 / \mathrm{S} 0100-204 X 2018000700009$ 